\title{
Value patterns of principal: an indicator of peaceful society for today and tomorrow
}

\begin{abstract}
School Principals are head of the organization and have to play diverse roles such as a leader, agent of instruction and discipline, a decision maker, a model for community and an inspirational leader for both students and staff. The various roles which principals play are basically directed by their values which are manifested in their every action. Values influence a specific mode of conduct because values contain the judgmental element which helps the principals in choosing the right, good or any other desirable action in a particular situation. The values manifested by the head are imbibed by the staff and students either voluntarily or involuntarily. Values in fact are determinants for a peaceful school and society as a whole. Objectives of the study were
\end{abstract}

\section{To study the value patterns among principals.}

2.To study the value pattern among principals with respect to their gender, experience and type of schools.

The sample comprised of 120 principals randomly selected from twelve districts of Delhi. Thus ten principals were selected from each district out of which five girl's schools and five boys' schools were taken. The personal value questionnaire of Sherry \& Verma1 was administered. Data analysis was done according to the objective of the study. The major findings indicated that value patterns and the magnitude of values were different. Democratic value had highest mean score followed by religions, knowledge, social, family prestige, economic, aesthetic, hedonistic, power and health value. Gender is found to be significant predictor of value pattern. The highest mean score is on democratic value and least on health value. The findings will help in developing appropriate procedures for selecting those principals who hold values essential for development of peaceful society.

Keywords: values, value patterns, principals, gender, types of schools
Volume 9 Issue 6 - 2018

\author{
Rubeena khan \\ Assistant Professor, GGSIP (IVS) University, India
}

Correspondence: Rubeena khan, Assistant professor, GGSIP (IVS), Awadh Bhawan ,Shaikh Sarai Phase II, New Delhi, India, Tel 9968098283, Email rubenakhan.s.prof@gmail.com

Received: July 09, 2018 | Published: November 28, 2018

\section{Introduction}

We are living in the world where there is an urgent need for peace, tolerance, and values. Since ages education is the medium to built character, develop integrated and holistic personality and to internalize right code of conduct and values in students. If the values and character of an individual is deteriorated it will ruin the whole generation and the future of such country will remain dubious. The demand from international perspective has been for the development of value based society so that we could have a secure and civilized society. The wholesome development of personality includes ethical development and ability of an individual to make responsible and positive decisions whenever individual is stuck in moral dilemmas. The society is dealing with the menace of degeneration of values in the youth of our country .Though India is on the road of rapid progress; still it requires proper value orientation and character building of its youth. Education is the only process which can contribute to the meaningful internalization of values for a peaceful future and world at large. As the famous proverb goes "Values cannot be taught but be caught", indicates that role models are essential to strengthen values in the system. Educational administrators and principals present the best role models in case of schools. Reason being that school culture depends upon the personal values of the administrators. School principals are responsible for creating the school climate. The values possessed by principals influence their actions and behaviours in different situations. It also guides the action and behaviour of the teachers and students. Values can be thought of forming an ideology that permeates everyday decisions. ${ }^{2}$ For inculcation of right values the principals have to possess right values themselves. When principals have acquired right values these permeates in their everyday decisions and actions. The school a child attends shapes his values, personality and his self concept. Values also depend upon the need dispositions and the personality of the principal. Thus one can regard values as the basic framework underlying the entire structure and focussing as motivations of the principals and influencing their action. So the values the principals and teachers manifests to the students remain inculcated in their minds. The values system within an individual guides him all throughout his life. Anna \& Seppo ${ }^{3}$ reported that values guide the behaviour of the principals in the respective directions. Asep ${ }^{4}$ reported that personal values of the principals had an impact on the effectiveness of the achievement of organizational goals. Leslie $^{5}$ reported that personal values of the school principals play an important role in their effective functioning. Notman ${ }^{6}$ further commented that principal's personal values are chief motivating factors in determining their behaviour and its future leads of spiritual intelligence, resilience and well being. $\mathrm{Kao}^{7}$ identified that the principal's values are responsible for important moral and value inculcation among students. In the Indian scenario various research findings further strengthened the fact that value based leadership is essential for progressive schools. Pradhan ${ }^{8}$ further pointed that principal of the school should lead his staff and students by setting example by himself and thus motivate his students and staff. Sehlat ${ }^{9}$ reported that principal's framework of 
values is requisite of the administrative skills and possession of values leads to growth of the institution and progress of the country. All the above mentioned research indicates that the educational administrators present the best role models in schools and the school culture depends on the personal values of the administrators. The values possessed by principals influence their actions and behaviour in different situations. It also guides the actions and behaviour of teachers. Values are thus acquired and if an individual experiences favourable situations he develop right values and if the individual is subjected to unfavourable situation then values which are developed are not right. The school a child attends shapes his values, personality and his self concept. The philosophy of the school and values imbibed by the teachers mould the personality of the child. The value system within an individual guides him all throughout their life. In the society where change is the only permanent thing and evils are creeping in like rotten creepers the need of the hour is the value based education. This cannot be achieved without value based teachers and principals.

\section{Operational definition}

Value Patterns: Value patterns refers to the personal values of an individual which encompasses Religious values, Social values, Democratic values, Aesthetic Value, Economic value, Knowledge value, Hedonistic value, Power value, Family prestige value and Health value where an individual / person act by selecting a mode of preference in a given situation.

\section{Methodology}

Objectives: The main objectives of the study were:

1. To study the value patterns among principals.

2. To study the value patterns among principals with respect to their gender, experience and type of schools.

\section{Variables}

\section{Independent variables}

Gender: Male and Female principals.

Experience: Less than 5 years and more than 5years

Type of schools: Girls schools, Boys Schools

\section{Dependent variable}

Value Patterns

\section{Sample}

The sample of the present study comprise of one hundred and twenty principals who were randomly drawn from twelve districts of Delhi. In this way ten principals were selected from each district, where an attempt was made to have an equal number of five girl schools and five boy schools.

\section{Tools and procedures}

\section{Scale}

The personal value questionnaire of Sherry $\&$ Verma $^{1}$ was selected for the present study. The scale measures ten values and consists of 40 questions spread over 120 items which assess values in terms of aspired aims, goal ideas or ways of action which constitute human behaviour choosy. The ten personal values mentioned in the Sherry and Verma scale are Religious values, Social Values, Demonatic Value, Aesthetic Value, Economic Value, Knowledge Value, Hedonistic Value, Power Value, Family Prestige Value, Health value. The reliability coefficient of the scale range from 0.57 to 0.70 and the validity is 0.64 .

\section{Scoring}

The scale has a typical scoring pattern as there are3(three) items / response category for each stem / questions since there are three response categories to the main question hence a score of 2(two) is given to the response where subjects have tick marked on the items showing more close to this idea and 1 (one) mark is given to the response category against which the subject has put a sign of cross showing 'least like him.' However the third response category which is unmarked is given zero. As Such the maximum score of the scale is 120 because each question can have a maximum score of the scale of 3 marks. The time limit of filling the questionnaire is forty minutes.

\section{Analysis}

According to the objectives the data was collected, scored and tabulated which was analyzed with the help of mean to determine the value patterns of principals and mean score was determined for all ten value as a whole and also with respect to gender, experience and type of schools.

\section{Results and discussion}

The Table 1 shows the mean score on different types of personal values possessed by school principal which range from 10.2 to 13.65 Here Democratic Value is Highest followed by religious values, which is 12.65, Knowledge Values 12.5, Social Value ie12.1, Economic Value 12.0 and Family Prestige Value 12.0 Aesthetic Value 11.8, Hedonistic Value 11.55, Power Value 10.5, and least score on Heath Value i.e.10.2 It can be seen that the most preferred value by most of the principals is Democratic value and least preferred is health values. Most of the principals put democratic value as highest priority and thus inculcate a sense of democratic approach in students. They are also high on religious values which can be inculcated in their students followed by knowledge value, here students can be motivated to gather more knowledge related aspects. However the hedonistic value is not so high thus they can motivate their students not to be pleasure seeking only and power value is also low thus the students should also put power value to least preferred domain. Thus a principal high on democratic value will definitely serve as a role model for these students. The high mean of democratic value suggest that by virtue of the nature of job of being administrator of the school they are supposed to be non-discriminative in all respect of social bonding and respect all equally (Table 2). The mean score is more among male principals on democratic value and in case of female principals they have fewer score on health value as compared to male principals. This depicts that male principals are non discriminative in all respect and have a notion of equality. Female principals are more ignorant about their health issues. The pattern of values is of more interest and worth of interpretation as among the male principals the religious and family prestige values are next to democratic a value which is followed by social values. This shows that male principals have equal regard for the family responsibilities along with maintaining the relationship with all the members. They are also God fearing and maintain ethical and religious rituals in their practices. They also believe in sympathy and kindness an indirect indicator of God fearing people. However their counter parts have the highest mean score on democratic value 
followed by knowledge and economic value besides family prestige value. This shows that the female principals are more concerned in finding the rationale of the activities in order to search the truth behind any action. Their preference of economic value and family prestige value further highlights the fact that perhaps they believe more in material standards besides the functions and duties of a family member. Such finding fits well in the study of Toong ${ }^{10}$ who noted the similar trends of value patterns among school teachers.

The Table 3 shows the mean score across experience on various types of values which range from 10.2 to 14.0 among principals with less than 5years experience and from 10.1 to 13.3 among principals with more than five years experience. The highest mean score among less experience principals is on democratic value and least on power value. Whereas among more experience principals the highest score is on democratic value and least is on health value. The trend of value pattern is also different among two groups. This denotes that being principals they are bound to respect individuality, the basic tenant of the democratic value but the observation of the least score on health value among more experienced principals shows that they are not able to maintain their fitness and remain engage in official functioning. However the presence of least mean score on power value among less experienced principals indicate that these principals do not have illegitimate desire either to rule over others or mislead them unnecessarily. The less experienced principals are having more rationale in their actions and decisions but the more experienced principals are more God fearing may be a sign of aging and therefore ethical practices are reflected in their behaviour. This is supported by a study of Asep ${ }^{4}$ who found that personal values impact on the effectiveness of achievement of organizational goals.

The Table 4 shows the mean score across type of schools on various types of personal values which range from 10.4 to 13.6 among girls school's principals and from 9.9to 13.7 among boys school principals. The highest mean score is on democratic value and the least is on health value among the boys and girls school principals. However the pattern of values is different among both the groups. This indicates that the principals of both types of schools respect the individual identity irrespective of the gender, caste religion and race. Moreover the principals being dutiful do not get sufficient time to maintain their physical fitness where the mean score is particularly low among the boys school principal. The girl school principals have family prestige value on the top followed by social and religious besides knowledge values and aesthetic values. This suggests that the female principals do consider the school in the format of family and try to have due respect for all. They are sympathetic to human or mankind as the values on social and religious value suggests. The knowledge value mean score is more among boys school principals meaning thereby that their task is being challenged more by the staff in search of the reason behind the particular act.

Table I Showing mean scores on different types of personal values possessed by school principals

\begin{tabular}{lllllllllll}
\hline $\begin{array}{l}\text { Type } \\
\text { of } \\
\text { values }\end{array}$ & $\begin{array}{l}\text { Religious } \\
\text { values }\end{array}$ & $\begin{array}{l}\text { Social } \\
\text { values }\end{array}$ & $\begin{array}{l}\text { Democratic } \\
\text { values }\end{array}$ & $\begin{array}{l}\text { Aesthetic } \\
\text { values }\end{array}$ & $\begin{array}{l}\text { Economic } \\
\text { Values }\end{array}$ & $\begin{array}{l}\text { Knowledge } \\
\text { values }\end{array}$ & $\begin{array}{l}\text { Hedonistic } \\
\text { values }\end{array}$ & $\begin{array}{l}\text { Power } \\
\text { Values }\end{array}$ & $\begin{array}{l}\text { Family } \\
\text { Prestige } \\
\text { value }\end{array}$ & $\begin{array}{l}\text { Health } \\
\text { Values }\end{array}$ \\
\hline $\begin{array}{l}\text { Mean } \\
\text { Score }\end{array}$ & 12.65 & 12.1 & 13.65 & 11.8 & 12 & 12.5 & 11.55 & 10.5 & 12 & 10.2 \\
\hline
\end{tabular}

Table 2 Showing mean comparison scores across gender on various type of personal values

\begin{tabular}{lllllllllll}
\hline $\begin{array}{l}\text { Type } \\
\text { of } \\
\text { values }\end{array}$ & $\begin{array}{l}\text { Religious } \\
\text { values }\end{array}$ & $\begin{array}{l}\text { Social } \\
\text { values }\end{array}$ & $\begin{array}{l}\text { Democratic } \\
\text { values }\end{array}$ & $\begin{array}{l}\text { Aesthetic } \\
\text { values }\end{array}$ & $\begin{array}{l}\text { Economic } \\
\text { Values }\end{array}$ & $\begin{array}{l}\text { Knowledge } \\
\text { values }\end{array}$ & $\begin{array}{l}\text { Hedonistic } \\
\text { values }\end{array}$ & $\begin{array}{l}\text { Power } \\
\text { Values }\end{array}$ & $\begin{array}{l}\text { Family } \\
\text { Prestige } \\
\text { value }\end{array}$ & $\begin{array}{l}\text { Health } \\
\text { Values }\end{array}$ \\
\hline $\begin{array}{l}\text { Mean } \\
\text { Score }\end{array}$ & 13.1 & 12.2 & 14 & 11.7 & 11.2 & 11.8 & 11.3 & 11.2 & 13.1 & 10.3 \\
Female & 12.2 & 12 & 13.3 & 11.9 & 12.8 & 13.2 & 11.8 & 10.3 & 12.3 & 10.1 \\
\hline
\end{tabular}

Table 3 Showing means comparison across experience on various types of personal values school principals

\begin{tabular}{|c|c|c|c|c|c|c|c|c|c|c|}
\hline Group & $\begin{array}{l}\text { Religious } \\
\text { values }\end{array}$ & $\begin{array}{l}\text { Social } \\
\text { values }\end{array}$ & $\begin{array}{l}\text { Democratic } \\
\text { values }\end{array}$ & $\begin{array}{l}\text { Aesthetic } \\
\text { values }\end{array}$ & $\begin{array}{l}\text { Economic } \\
\text { Values }\end{array}$ & $\begin{array}{l}\text { Knowledge } \\
\text { values }\end{array}$ & $\begin{array}{l}\text { Hedonistic } \\
\text { values }\end{array}$ & $\begin{array}{l}\text { Power } \\
\text { Values }\end{array}$ & $\begin{array}{l}\text { Family } \\
\text { Prestige } \\
\text { value }\end{array}$ & $\begin{array}{l}\text { Health } \\
\text { Values }\end{array}$ \\
\hline $\begin{array}{l}\text { Less } \\
\text { than } 5 \\
\text { years }\end{array}$ & 12.3 & 11.9 & 14.0 & 12.0 & 12.1 & 13.4 & 11.3 & 10.1 & 12.6 & 10.2 \\
\hline $\begin{array}{l}\text { More } \\
\text { than } 5 \\
\text { years }\end{array}$ & 13.0 & 12.3 & 13.3 & 11.6 & 11.9 & 11.7 & 11.7 & 11.3 & 12.8 & 10.1 \\
\hline
\end{tabular}


Table 4 Showing mean comparison across schools on various types of personal values among school principals

\begin{tabular}{llllllllll}
\hline Group & $\begin{array}{l}\text { Religious } \\
\text { values }\end{array}$ & $\begin{array}{l}\text { Social } \\
\text { values }\end{array}$ & $\begin{array}{l}\text { Democratic } \\
\text { values }\end{array}$ & $\begin{array}{l}\text { Aesthetic } \\
\text { values }\end{array}$ & $\begin{array}{l}\text { Economic } \\
\text { Values }\end{array}$ & $\begin{array}{l}\text { Knowledge } \\
\text { values }\end{array}$ & $\begin{array}{l}\text { Hedonistic } \\
\text { values }\end{array}$ & $\begin{array}{l}\text { Power } \\
\text { Values }\end{array}$ & $\begin{array}{l}\text { Family } \\
\text { Prestige } \\
\text { Value }\end{array}$ \\
\hline Girls & 12.5 & 12.5 & 13.6 & 12 & 11.8 & 12.2 & $\begin{array}{l}\text { Health } \\
\text { Values }\end{array}$ \\
Boys & 12.1 & 11.6 & 13.7 & 11.5 & 12.2 & 12.9 & 1.4 & 11.2 & 12.7 \\
\hline
\end{tabular}

\section{Major findings}

1. Among all principals the highest mean score is on democratic value and least mean core is on health value.

2. Economic and knowledge Value are observed more among female principals.

3. Democratic Value is most preferred among less experienced principals whereas Power Value is more among more experiences principals.

4. Democratic Value is more among male principals.

5. The highest mean score is on democratic value among the boys and girls school principals.

6. The least mean score is on health value among the boys and girls school principals.

\section{Conclusion}

It may be concluded that economic knowledge values have a difference in respect of the gender, where females have more scores on these values. Democratic value is also noted more among the principals who are less experienced but power value is more among more experienced Principals. Democratic values has been found to be of highest mean score among principals irrespective of gender, experience and types of schools and least score is on power value.

\section{Educational implications}

1. The personal values of the principals should be checked before their selections.

2. Their posting be made after psychological testing. As carried out for other services because students catches the values which are manifested by principals and teachers.

\section{Acknowledgments}

None

\section{Conflicts of interest}

The author declares that there is no conflicts of interest.

\section{References}

1. Sherry GP, Verma RP. Personal Value Questionnaire. National Psychological Corporation, Agra. 1998.

2. Koontz H, Weihrich H. Essential of Management. $5^{\text {th }}$ ed. Singapore: MC Graw Hill. 1990.

3. Anna U, Seppo S. Procedia Social and Behavioural Science. World Conference on Learning, Teaching and Administration. 2010;9:1-2090.

4. Asep S. Personal Values and Commitment in Achieving Goal through the Cultural Organization of Work. The Journal of Value Based Leadership. 2010;3(2)

5. Leslie. Leadership in Higher Education. Doctoral Thesis, Pepperdine University. 2006.

6. Notman, GR. The Principals as a person; A study of values in Secondary School leadership, Doctoral Thesis, Massey University, Patmerston North, New Zealand; 2005.

7. Kao TC. High School Principals Values and their symbolic and Cultural Leadership Approaches to Character Education in China, University of San Diego, Doctoral Thesis. 2005.

8. Pradhan N. Value based Leadership for progressive Schools, Conference, Gujarat Council of Educational Administration and Management. 2000.

9. Sehlat N. Values in Relation to Leadership and Institutional Effectiveness in Education Conference, Gujarat Council of Educational Administration and Management. 2000.

10. Toong R. Value Patterns of school Teacher in Relation to life Satisfaction and Personality Dimensions, Punjab University; 2007. 